\title{
Immune Thrombocytopenia Associated with Mycoplasma pneumoniae Infection
}

\author{
Catarina Gouveia, Vasco Evangelista, Raquel Almeida, Antonio Martins Baptista \\ Beatriz Ângelo Hospital, Loures, Portugal
}

Received: $13 / 12 / 2017$

Accepted: $18 / 12 / 2017$

Published: $22 / 01 / 2018$

How to cite this article: Gouveia C, Evangelista V, Almeida R, Martins Baptista A. Immune thrombocytopenia associated with Mycoplasma pneumoniae infection. EJCRIM 2018;5: doi:10.12890/2018_000817.

Conflicts of Interests: The Authors declare that there are no competing interests.

This article is licensed under a Commons Attribution Non-Commercial 4.0 License

\section{ABSTRACT}

Immune thrombocytopenia (ITP) related to Mycoplasma pneumoniae infection is a rare condition and usually associated with a severe clinical course. We here report a case of a young man with a clinical diagnosis of severe ITP secondary to M. pneumoniae infection. The clinical features, therapy and outcome are presented.

\section{LEARNING POINTS}

- Immune thrombocytopenia (ITP) related to Mycoplasma pneumoniae infection is a rare condition.

- ITP secondary to M. pneumoniae infection appears to be associated with a more severe and refractory clinical course.

- It remains unclear whether specific anti-Mycoplasma antibiotic therapy is associated with a milder clinical course and a better prognosis.

\section{KEYWORDS}

Immune thrombocytopenia, Mycoplasma pneumoniae, rituximab

\section{INTRODUCTION}

Immune thrombocytopenia (ITP) is one of the more common causes of thrombocytopenia in otherwise healthy adults. Thrombocytopenia associated with $\mathrm{M}$. pneumoniae infection is a rare condition which usually has a severe course. We report the case of a young man with a clinical diagnosis of severe ITP that was associated with M. pneumoniae infection. Extra-pulmonary features of M. pneumoniae infection occur in $20-25 \%$ of cases, with the most commonly associated haematological abnormality being haemolytic anaemia due to the formation of cold agglutinin antibodies against erythrocyte I antigen ${ }^{[1]}$. Thrombocytopenia associated with M. pneumoniae is usually associated with thrombotic thrombocytopenic purpura or disseminated intravascular coagulation, but association with ITP is rare.

\section{CASE DESCRIPTION}

A 24-year-old male college student was admitted to the emergency department with a 1-day history of reddish lesions on both legs (Fig. 1), a tongue haematoma following accidental bite (Fig. 2) and two small back bruises, self-induced after pinching himself. He remembered having odynophagia and serous rhinorrhoea without a cough or fever 2 weeks before admission. With a history of infectious mononucleosis at the age of 16 , he had had recurrent tonsillitis ever since. He was physically very active and his medication history included protein supplements and a one-time-only use of sildenafil. 




Figure 1. Reddish lesions on both legs suggestive of petechiae and purpura of the inferior limbs

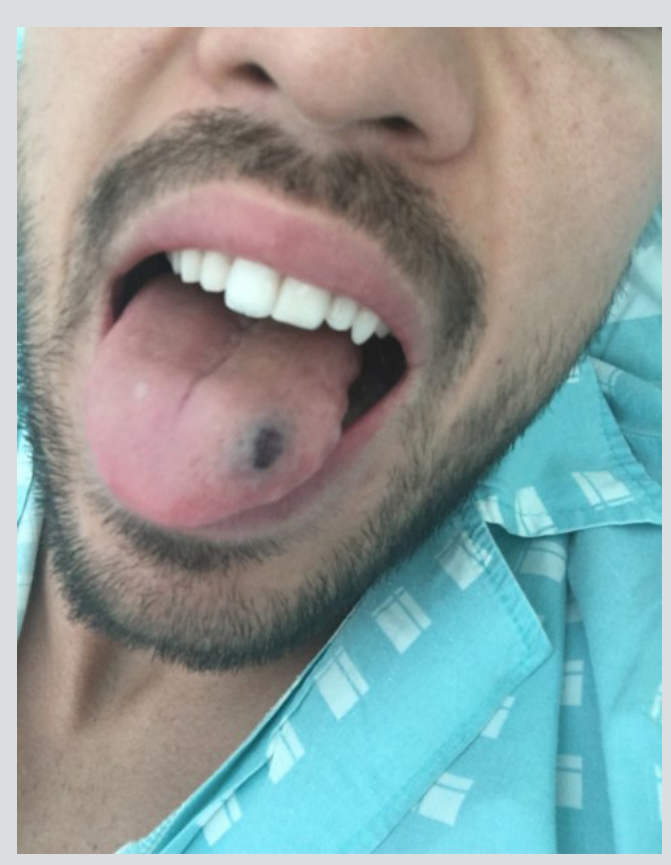

Figure 2. Tongue haematoma

Initial evaluation revealed normal vital signs, with a body temperature of $36.7^{\circ} \mathrm{C}$, blood pressure of $132 / 61 \mathrm{mmHg}$, pulse rate of 54 beats/ min and $\mathrm{O}_{2}$ saturation of $100 \%$ on room air. He had petechial and purpuric lesions on both legs, slightly palpable hepatosplenomegaly and no identifiable adenopathies. The remaining physical examination was normal.

Complete blood count showed haemoglobin of $14.6 \mathrm{~g} / \mathrm{dl}$, leucocyte count of $5.7 \times 10^{9} \mathrm{cells} / \mathrm{I}$ and platelet count of $3 \times 10^{9} \mathrm{cells} / \mathrm{l}$. Coagulation, liver and renal studies were normal. CRP was $1.15 \mathrm{mg} / \mathrm{dl}$. A peripheral blood smear confirmed severe thrombocytopenia without abnormal cells. A chest $x$-ray did not show any signs of pleuroparenchymal lung disease and abdominal ultrasound confirmed the presence of moderate homogeneous hepatosplenomegaly.

A presumptive diagnosis of ITP was made, corticoid treatment was promptly initiated and the patient was hospitalized. No platelet count response was seen following a 3-day course of methylprednisolone $1 \mathrm{~g} \mathrm{IV}$. Oral prednisolone $1 \mathrm{mg} / \mathrm{kg} / \mathrm{day}$ and a 3-day course of intravenous immunoglobulin (IVIG) $1 \mathrm{~g} / \mathrm{kg}$ was therefore initiated with an increase in platelet count to $48 \times 10^{9}$ cells/I the day after. However, on the very next day, the platelet count dropped once again to $2 \times 10^{9}$ cells/I. A second 3-day course of methylprednisolone $1 \mathrm{~g}$ IV in association with 4 more days of IVIG $1 \mathrm{~g} / \mathrm{kg}$ was given with no platelet response. The patient remained clinically stable until the 11 th day of hospitalization when he presented with epistaxis (Fig. 3), gingival haemorrhage, vascular puncture site haematoma (Fig. 4) and new petechiae on the face and trunk. Prednisolone dosage was increased to $1.5 \mathrm{mg} / \mathrm{kg} /$ day and the anti-CD20 monoclonal antibody rituximab $375 \mathrm{mg} / \mathrm{m}^{2} \mathrm{IV}$ was also initiated. Bone marrow examination revealed normal cellularity with megakaryocytic hyperplasia but no cell abnormalities, compatible with the diagnosis of ITP. A thoraco-abdomino-pelvic CT scan did not show any lymphadenopathies or lesions suggestive of a neoplastic process. Serological testing for EBV, CMV, HCV, HBV, HIV, HSV and parvovirus B19 was negative for acute infection. Aurea breath test for Helicobacter pylori was negative. Assays for ANA, dsDNA, rheumatoid factor, anticardiolipin, lupus anticoagulant and anti-beta-2 glycoprotein were also negative. Antiplatelet antibodies were positive and a positive M. pneumoniae IgM titre was found. ITP secondary to M. pneumoniae infection was assumed, and clarithromycin $500 \mathrm{mg}$ twice a day was added to the treatment regimen.

By the $14^{\text {th }}$ day of hospitalization the platelet count was still $4 \times 10^{9}$ cells $/$ and the patient presented with gross haematuria. As a consequence, two pools of platelets were given and he was transferred to the intermediate care unit for closer observation. He became hypertensive (blood pressure of 170/90 mmHg), anaemic (with haemoglobin dropping to $8.9 \mathrm{~g} / \mathrm{dl}$ ) and developed a constant headache and occasional haemolacria (Fig. 5). A cranial CT scan excluded any haemorrhagic lesions.

Six days after the second dose of rituximab (on the 24 th day of hospitalization), the platelet count slowly started to rise to $21 \times 10^{9}$ cells/l. 


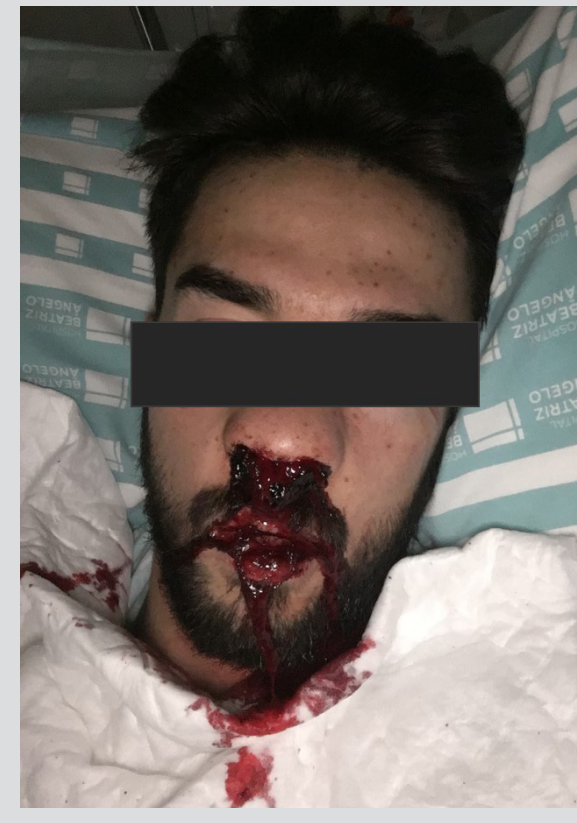

Figure 3. Epistaxis

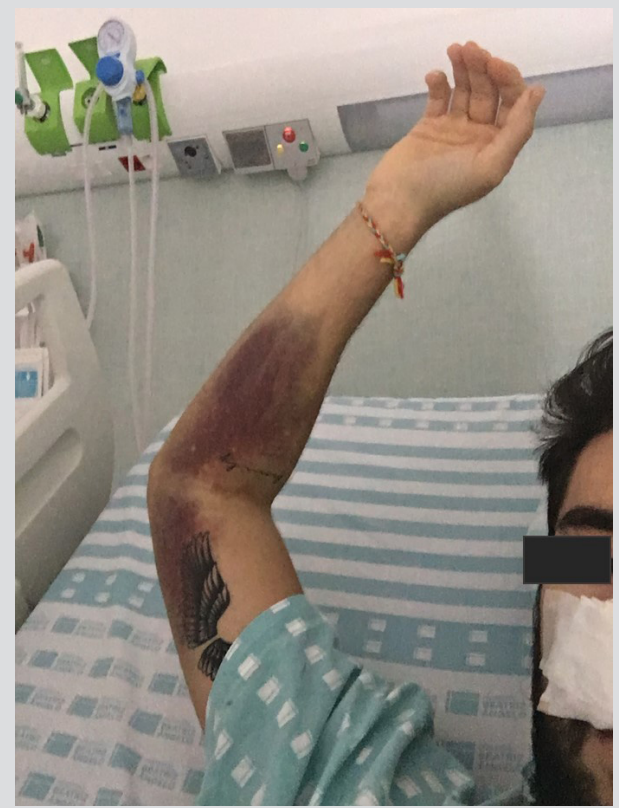

Figure 4. Vascular puncture site haematoma

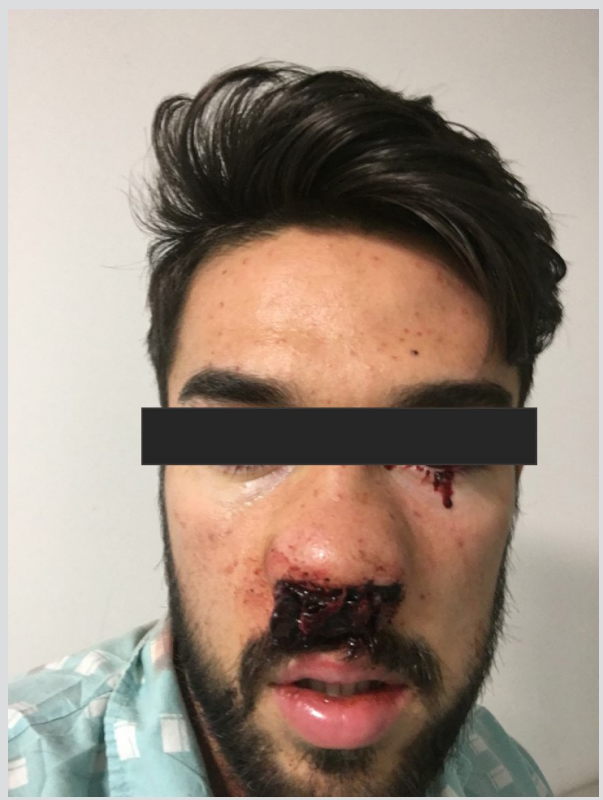

Figure 5. Haemolacria

Given the subsequent resolution of haematuria and other haemorrhagic dyscrasia, the dose of oral prednisolone was reduced to $1 \mathrm{mg} / \mathrm{kg} /$ day and the patient was transferred back to the medicine ward, where he completed treatment with rituximab.

From the 25 th day of hospitalization onwards, the platelet count gradually increased, as did haemoglobin values. The patient was discharged on the 28th day after admission with a platelet count of $229 \times 10^{9}$ cells/l and no signs of blood dyscrasia. He returned for 2 -week follow-up asymptomatic and with a platelet count of $273 \times 10^{9}$ cells/l, slowly tapering oral prednisolone as advised upon discharge.

\section{DISCUSSION}

Haematological abnormalities associated with Mycoplasma infection are widely described, but association with ITP is rarely reported ${ }^{[2]}$. We identified 10 similar case reports in a literature research. Table 1 summarizes the clinical features and outcomes of those cases. Most patients ( 7 out of 10) were male and the mean age was 18 years (ranging from 7 months to 64 years). The most common clinical presentation was respiratory infection (cough, fever and dyspnoea) and mild haemorrhagic manifestations (petechiae, purpura and epistaxis). Two patients presented with more severe forms of haemorrhage (haemoptysis, haematuria and haematochezia), while three patients did not have any haemorrhagic symptoms at all. The mean platelet count on admission was $11 \times 10^{3}$ cells/l. Apart from one patient, all subjects underwent corticosteroid therapy. In three of them IGIV therapy was given as well. Empiric antimicrobial therapy was administered to eight patients, targeting atypical bacteria, in most cases through macrolide usage. Interestingly, none of the patients required rituximab. The mean time required for platelets to rise above $150 \times 10^{3}$ cells/I was 21 days. In most cases evidence for Mycoplasma infection came from a complement fixation test, cold agglutinin test or IgM titre. Two patients experienced intracranial haemorrhage and died. Although incompletely understood, the pathogenesis of ITP is thought to involve the formation of specific autoantibodies against platelet cell membrane glycoproteins, more commonly GPIIb/IIla ${ }^{[3]}$.

In up to $60 \%$ of patients, M. pneumoniae infection manifests itself only by odynophagia and rhinorrhoea, as in our patient.

Several physiopathological mechanisms have been described to explain the production of antiplatelet antibodies following Mycoplasma infection, such as molecular mimicry, the development of immune complexes that may cause platelet aggregation, serotonin release, and clearance of platelets ${ }^{[4]}$ and even direct binding of Mycoplasma to the platelets, generating a complex that is then recognized as foreign by the immune system.

Secondary ITP associated with M. pneumoniae infection appears to have a more severe clinical course and, to some extent, to be a refractory disease, as evidenced by the referenced cases and our own.

About $66 \%$ of patients with ITP respond to steroid therapy after 1-2 weeks. Our patient was found to be corticosteroid resistant which first led to the need to initiate IGIV therapy and later, given the poor clinical response, to second-line therapy with rituximab. 
Rituximab is a monoclonal antibody directed against the B cell surface protein CD20. Response to this therapy can occur within a week but may take up to 2 months. In this case our patient had a partial response on day 14 and a complete response after 15 days of rituximab therapy.

Specific anti-Mycoplasma therapy was initiated but, in our case, had no apparent effect on the clinical course or outcome, so given the very few cases described, we cannot evaluate the benefit of this particular therapy.

\section{CONCLUSION}

Considering the clinical features described above, ITP secondary to M. pneumoniae infection appears to be associated with a more severe and refractory clinical course. It remains unclear whether specific anti-Mycoplasma antibiotic therapy is associated with a milder clinical course and a better prognosis.

\begin{tabular}{|c|c|c|c|c|c|c|c|}
\hline Case & Age (yrs) Sex & Clinical Presentation & $\begin{array}{l}\text { Platelets on } \\
\text { admission } \\
\left(\times 10^{3} \text { cells/l) }\right.\end{array}$ & $\begin{array}{l}\text { Mycoplasma } \\
\text { testing }\end{array}$ & Complications & Treatment & $\begin{array}{l}\text { Time to platelets } \\
>150 \\
\left(\times 10^{3} \mathrm{cell} / \mathrm{s} / \mathrm{l}\right)\end{array}$ \\
\hline Current case & 24, Male & $\begin{array}{l}\text { Petechiae and purpura, } \\
\text { odynophagia and serous } \\
\text { rhinorrhoea } \\
2 \text { weeks previously }\end{array}$ & 3 & $\lg M 29.9$ & $\begin{array}{l}\text { Epistaxis, gingival } \\
\text { haemorrhage, } \\
\text { haematuria, } \\
\text { haemolacria, } \\
\text { anaemia and } \\
\text { headache }\end{array}$ & $\begin{array}{l}\text { Methylprednisolone, } \\
\text { IVIG, prednisolone, } \\
\text { rituximab, } \\
\text { clarithromicin }\end{array}$ & 28 days \\
\hline Tsai et al..$^{[5]}$ & 0,7 , Female & $\begin{array}{l}\text { Cough, fever, dyspnoea } \\
\text { (pneumonia) and petechiae }\end{array}$ & 14 & $\begin{array}{l}\text { Complement } \\
\text { fixation test 1:4; } \\
\text { cold agglutinin } \\
\text { 1:128 }\end{array}$ & None & $\begin{array}{l}\text { Prednisolone, } \\
\text { minocycline }\end{array}$ & 14 days \\
\hline Miller et al. ${ }^{[6]}$ & 44, Male & $\begin{array}{l}\text { Cough, fever (pneumonia), } \\
\text { haematuria }\end{array}$ & 7 & $\begin{array}{l}\text { Complement } \\
\text { fixation test 1:4 to } \\
\text { 1:32; cold } \\
\text { agglutinin 1:128 }\end{array}$ & $\begin{array}{l}\text { Brain stem } \\
\text { haemorrhage, } \\
\text { death on day } 14\end{array}$ & $\begin{array}{l}\text { Erythromycin, } \\
\text { cefotaxime, } \\
\text { amikacin, } \\
\text { methylprednisolone }\end{array}$ & Never \\
\hline Veenhoven et al. ${ }^{[7]}$ & 17, Male & $\begin{array}{l}\text { Cough, fever, dyspnoea } \\
\text { (pneumonia) and petechiae }\end{array}$ & 25 & $\begin{array}{l}\text { Complement } \\
\text { fixation test 1:64; } \\
\text { lgM+cold } \\
\text { agglutinin 32-256 }\end{array}$ & None & $\begin{array}{l}\text { Prednisolone, } \\
\text { erythromycin }\end{array}$ & 3 months \\
\hline Beattie $^{[8]}$ & 4, Male & Cough, fever (pneumonia) & 4 & $\operatorname{lgM} 80-320$ & $\begin{array}{l}\text { Purpura, epistaxis } \\
\text { and haematuria }\end{array}$ & IGIV & $\begin{array}{l}\text { Not mentioned, } \\
42 \times 10^{3} \text { cells/l } \\
\text { on day } 5\end{array}$ \\
\hline Pugliese et al. ${ }^{[9]}$ & 7, Male & Sinusitis, fever & $<18$ & $\begin{array}{l}\text { ELISA 1.01; } \\
\text { cold agglutinin 1:64 }\end{array}$ & $\begin{array}{l}\text { Headache, } \\
\text { vomiting, diarrhoea }\end{array}$ & $\begin{array}{l}\text { Ceftriaxone, } \\
\text { erythromycin, } \\
\text { prednisone }\end{array}$ & 14 days \\
\hline Isoyama et al. ${ }^{[10]}$ & 8, Male & $\begin{array}{l}\text { Rhinorrhoea, cough, } \\
\text { epistaxis, petechiae and } \\
\text { haematoma of the skin }\end{array}$ & 2 & $\begin{array}{l}\text { ELISA } 4 \text { to }>1.5 \\
3 \text { positive cultures }\end{array}$ & $\begin{array}{l}\text { Epistaxis, } \\
\text { haematuria and } \\
\text { haematochezia }\end{array}$ & Prednisone, IVIG & 14 days \\
\hline Venkatesan et al. ${ }^{[11]}$ & 21, Male & $\begin{array}{l}\text { Cough, fever (pneumonia), } \\
\text { purpura, haemoptysis, } \\
\text { haematuria and } \\
\text { haematochezia }\end{array}$ & 6 & $\begin{array}{l}\text { Complement } \\
\text { fixation test } \\
\text { 1:8000; } \\
\text { total anti-mycoplasma } \\
\text { 1:5120 }\end{array}$ & $\begin{array}{l}\text { Intracranial } \\
\text { haemorrhage; } \\
\text { death on day } 2\end{array}$ & $\begin{array}{l}\text { Cefotaxime, } \\
\text { methylprednisolone, } \\
\text { erythromycin }\end{array}$ & Never \\
\hline $\begin{array}{l}\text { Scimeca and James- } \\
\text { Herry }{ }^{12]}\end{array}$ & 7, Male & Otitis media, fever & 5 & $\begin{array}{l}\text { Mycoplasma } \\
\text { pneumoniae titre } \\
\text { and antibody }\end{array}$ & Petechiae & $\begin{array}{l}\text { Amoxicillin, } \\
\text { erythromycin, } \\
\text { prednisone }\end{array}$ & 1 week \\
\hline Okoli et al. ${ }^{[13]}$ & 64, Female & $\begin{array}{c}\text { Cough, dyspnoea, epistaxis, } \\
\text { purpura and bruising }\end{array}$ & 3 & IgM+cold agglutinin & None & $\begin{array}{l}\text { Moxifloxacin, } \\
\text { dexamethasone } \\
40 \mathrm{mg}\end{array}$ & 3 months \\
\hline Aviner et al..$^{14]}$ & 7, Female & $\begin{array}{l}\text { Cough, fever (pneumonia), } \\
\text { petechiae and } \\
\text { purpura }\end{array}$ & 2 & $\begin{array}{l}\text { IgM+total } \\
\text { anti-mycoplasma } \\
1: 64\end{array}$ & Haemoptysis & $\begin{array}{l}\text { IVIG, prednisolone, } \\
\text { clarithromycin }\end{array}$ & 2 months \\
\hline
\end{tabular}

Table 1. Clinical features and outcomes of Mycoplasma infection-associated immune thrombocytopenia 


\section{REFERENCES}

1. Waites KB, Talkington DF. Mycoplasma pneumoniae and its role as a human pathogen. Clin Microbiol Rev 2004;17:697-728.

2. Kottayam R, Rozenberg G, Cohn RJ. Unusual haematologic manifestations of Mycoplasma pneumoniae infection. J Paediatr Child Health 2007;43:80-82.

3. Cines DB, Blanchette VS. Immune thrombocytopenic purpura. N Engl J Med 2002;346:995-1008.

4. Biberfeld G, Norberg R. Circulating immune complexes in Mycoplasma pneumoniae infection. J Immunol 1974;112:413-415.

5. Tsai YM, Lee PP, Liu CH. A case of primary atypical pneumonia complicated with severe thrombocytopenia. Taiwan Yi Xue Hui Za Zhi 1985;84:742-746.

6. Miller SN, Ringler RP, Lipshutz MD. Thrombocytopenia and fatal intracerebral hemorrhage associated with Mycoplasma pneumonia pneumonia. NY State J Med 1986; 86:605607.

7. Veenhoven WA, Smithuis RH, Kerst AJ. Thrombocytopenia associated with Mycoplasma pneumoniae infection. Neth J Med 1990; 37:75-76.

8. Beattie RM. Mycoplasma and thrombocytopenia. Arch Dis Child 1993; 68:250.

9. Pugliese A, Levchuck S, Cunha BA. Mycoplasma pneumoniae induced thrombocytopenia. Heart Lung 1993; 22:373-375.

10. Isoyama K, Yamada K. Previous Mycoplasma pneumoniae infection causing severe thrombocytopenic purpura. Am J Hematol 1994; 47:252-253.

11. Venkatesan P, Patel V, Collingham KE, Ellis CJ. Fatal thrombocytopenia associated with Mycoplasma pneumoniae infection. J Infect $1996 ; 33: 115-117$.

12. Scimeca PG, James-Herry AG. Severe, acute thrombocytopenia complicating Mycoplasma infection. Pediatr Hematol Oncol 1994; 11:557-559.

13. Okoli K, Gupta A, Irani F, Kasmani R. Immune thrombocytopenia associated with Mycoplasma pneumonia infection: a case report and review of literature. Blood Coagul Fibrinolysis 2009;20: 595-8

14. Aviner S, Miskin H, London D, Horowitz S, Schlesinger M. Mycoplasma pneumonia infection: A possible trigger for immune thrombocytopenia. Indian J Hematol Blood Transfus 2011; 27:46-50. 